\title{
The mediating effect of organizational citizenship behavior on the relationship between workplace spirituality and intention to leave
}

\author{
Roya Anvari ${ }^{1}$ (D), Ali Shaemi Barzaki ${ }^{1}$ (D), Leyla Amiri² (iD), Sobia Irum²(iD), Sholeh Shapourabadi²(iD \\ ${ }^{1}$ University of Isfahan (Iran) \\ ${ }^{2}$ Ragheb Isfahani Higher Education Institute (Iran) \\ ryanvari@yahoo.com, alishaemi@yahoo.com,_amiri170@yahoo.com, sobiasafdar@yaboo.com,noorestan86@yahoo.com
}

Received October, 2016

Accepted January, 2017

\section{Abstract}

Purpose: This study aims to explore the relationships between workplace spirituality, intention to leave and organizational citizenship behaviour (OCB) among nurses and whether OCB mediates the relationship between workplace spirituality and intention to leave.

Design/methodology: Due to the shifting paradigm of health policies, administrations in Malaysian hospitals are faced with trials of cost reduction. The high rate of nurses leaving the hospital poses a burden to the human resource department. This study aims to discover how to cope with this problem by utilizing workplace spirituality and organizational citizenship behaviour. In the present correlational study, data were collected using questionnaires. A total of 345 nurses from three public and general hospitals located in Johor Bahru, Malaysia, were chosen as samples using a random sampling method to respond to questionnaires. The measurement and structural model were assessed using SmartPls 2.0.

Findings: Workplace spirituality has significant negative influence on nurses' intention to leave and positive influence on OCB. Amongst nurses, workplace spirituality contributed to $34 \%$ of the variation in intention to leave, whereas $36 \%$ of the variation was in accordance to OCBI 
and $45 \%$ of the variation was in accordance to OCBO. Furthermore, OCB arbitrated the effect of workplace spirituality on the intention to leave.

Social implications: This study has shown the probable advantages of better understanding the positive impact of workplace spirituality on nurses' tendency to leave and OCB. This is important for the managers of nurses in the effort to improve nurses' performance and, by extension, the healthcare system.

Originality/value: Workplace spirituality contributes to nurses' intention to leave and OCB. This study highlights the benefits of the novel idea of workplace spirituality, especially amongst nurses needing motivation in their duties.

Keywords: Workplace spirituality, Intention to leave

Jel Codes: $\mathrm{I} 1$

\section{Introduction}

Nurses must possess a holistic approach, good communicative and collaborative skills, because they encounter patients frequently in the healthcare landscape. Organizational changes tend to affect work relationships and conditions, which ultimately affects employees (Hicks, 2003). Due to such changes, more and more nurses tend to resign, causing increased burdens for the remaining ones. Consequently, the remaining nurses are faced with increasing challenges, such as interference in work, deteriorating motivation and performance, lower patient care quality, absenteeism, and additional resignations (Laschinger, Finegan \& Shamian, 2001; Altuntas \& Baykal, 2010). To curb the aforementioned challenges, nurses must trust their managers, institutions and co-workers to support them, as these individuals can help improve the satisfaction for both patients and nurses and, at the same time, enhance motivation, performance, and commitment to the organization, thus leading to fewer resignations (Altuntas \& Baykal, 2010). Because of the separation of work from community and life, the perception that work is an essential part of life is lacking (Chalofsky \& Krishna, 2009). Physically, the employees' bodies and brains are present at their work, but they are not spiritually present. Therefore, as a new approach to consider organizational accomplishment and performance, work place spirituality values were proposed. Workplace spirituality focuses on the people who consider themselves 
as spiritual humans, whose souls need and want to rejuvenate via work (Ashmos \& Duchon, 2000). Spirituality results from employees sharing and sensing a connection, attraction and closeness with their colleagues on their team and in the organization as a whole (Harrington, Preziosi \& Gooden, 2004). This new idea aids in predicting lower tendency to resign, there by positively influencing the performance and effectiveness of the whole organization (Hong, 2012). Moreover, the success and efficacy of an organization can be influenced by the growing understanding and inverse relationship of workplace spirituality and intention to leave as behavioural outcomes. Nevertheless, it is very difficult to provide a highly effective organizational environment required for employees to flourish beyond their assigned tasks (Tsai \& Wu, 2010). Many management systems look to organizational citizens hip behaviour (OCB) for this purpose (Organ, Podsakoff \& MacKenzie, 2006). According to Organ (1988), OCB is defined as a discretionary behaviour of a person who is not related to any official reward mechanism and who, as a whole, helps a company to operate efficiently. With a better understanding of the benefits of workplace spirituality towards OCB, organizations can be more successful and effective. Therefore, for this study, the concept of workplace spirituality is a novel idea for hospital managers in order to attract and retain their nurses.

Hence, the main purpose of this study is to explore the relationships between workplace spirituality, tendency to resign, and OCB among nurses. In addition, the study aims to examine the direct and in direct associations between workplace spirituality and intention to leave with OCB as the major positive attitude.

\section{Literature review and hypotheses}

\subsection{Relationships among workplace spirituality, intention to leave and organizational}

\subsubsection{Citizenship behaviour}

The nursing sector claims to provide holistic care for all patients and acknowledges the need to focus on spirituality. Kazemipour, Mohamad Amin and Pourseidi (2012) suggests that fulfilling the spiritual needs of patients is an important aspect of providing holistic nursing care to patients. Pesut (2013) states that the relationship between health care profession like nursing, and spirituality has an extensive history. Nevertheless, nurses do late sittings, work on the weekends and holidays, and, while taking care of the admitted patients, frequently have to do work that many people would consider hard and unpleasant. All of these factors would presumably result in low job satisfaction (Lazar, 2010). An 
organization's ability to fulfil patients' essential needs and provide excellent services can be adversely affected by high turnover of nurses (Hayes et al., 2006). The short age is worsened by nurses' absences from work. Thus, absence is a serious issue during severe shortages. Moreover, turnover and work absences are costly for employers and lead to lower quality of patient care (Heinen et al., 2013). The efficacy of organizations, especially in the health care industry, is significantly influenced by turnover and absences. High nurse turnover rates and low attendance are key explanations for the increased attention on behaviours in the health care industry (Cohen \& Golan, 2007; Heinen et al., 2013). Despite the aforementioned problems that nurses face, workplace spirituality maybe an effective approach to decrease the intention to leave (Hong, 2012). Presumably, spiritual nurses will find their profession more in line with their own needs and will be more content with their duties (Cohen \& Golan, 2007). Meanwhile, this idea as a new concept foresees decreased intention to leave, which significantly affects organizational performance and, by extension, organizational effectiveness (Hong, 2012; Milliman, Czaplewski \& Ferguson, 2003). Krishnakumar and Neck (2002) performed a study on the advantages that workplace spirituality brings to organizational outcomes. Hence, workplace spirituality is considered a key factor that increases employees' happiness. Some researchers have proposed that happy employees are more cooperative, respect others more, and are more inclined to demonstrate OCB (Avey, Wernsing \& Luthans, 2008; Whitman, Van Rooy \& Viswesvaran, 2010). Thus, Podsakoff, Whiting, Podsakoff and Blume (2009) showed an inverse relationship between OCB and intention to leave. A better understanding of the benefits of workplace spirituality to OCB provides organizations with better chances of success and high effectiveness. Showing empathy and compassion, as well as fostering good emotionalties with patients, are important for nurses given the large amount of time they spend with patients (Carroll, 2001). In addition, nurses have more chances to provide spiritual care and foster emotional relationships with patients due to their extensive involvement (Komala \& Ganesh, 2007). According to Kazemipour et al. (2012), the higher workplace spirituality is, the better the OCB performance is among nurses. Nurses who have a better grasp of meaning and purpose from their working experiences tend to practice OCB behaviours more. As such, there is a strong relationship between spirituality and healthcare, particularly in regard to nurses. Furthermore, workplace spirituality encourages staff members to demonstrate more instances of $\mathrm{OCB}$ and fewer negative signs of intention to leave. Employees who are interested, true to their work, and more cooperative and flexible towards organizational change exhibit fewer signs of the intention to resign from their organizations (Milliman et al., 2003; Hong, 2012).

Even though the positive link between workplace spirituality and organizational behavioural outcomes has been shown (almost theoretically), certain studies stress empirical investigation. However, the 
meaningful work, sense of community and positive organizational purpose are the dimensions of workplace spirituality in investigating this relationship with the dimensions of OCB (OCBI and OCBO). OCBI are those behaviours from which certain people in the organization benefit instantly; thus, they implicitly help in the efficacy of an organization (Lee \& Allen, 2002; Williams \& Anderson, 1991). This dimension was called "helping behavior" by Podsakoff, MacKenzie, Paine \& Bachrach (2000) and was described by them as willingly helping other people to solve their work issues. OCBO are the behaviours that benefit the organization and are not explicitly targeted towards any person or people within the organization, such as following informal rules and serving voluntarily on committees. Podsakoff et al (2000) called this organizational compliance, because a company's rules and policies formed an integral part of employee beliefs. Moreover, Williams and Anderson (1991) described OCBO as behaviours that generally help the company overall. According to the previous studies referenced above, workplace spirituality can be deemed applicable to decrease intention to leave and increase OCB among nurses. This study was carried out to investigate the influence of workplace spirituality on the intention to leave and organizational citizen ship behaviour among nurses. With this idea as the core concept, the following hypotheses were developed:

Meaningful work and intention to leave a reinversely related (H1).

Sense of community and intention to leave are inversely related (H2).

Positive organizational purpose and intention to leave are inversely related $(\mathrm{H} 3)$.

Meaningful work and OCBI are directly related to each other (H4).

Sense of community and OCBI are directly related to each other (H5).

Positive organizational purpose and OCBI are directly related to each other (H6).

Meaningful work and $\mathrm{OCBO}$ are directly related to each other (H7).

Sense of community and OCBO are directly related to each other (H8).

Positive organizational purpose OCBO are directly related to each other (H9).

OCBI and intention to leave are inversely related to each other (H10).

OCBO and intention to leave are inversely related to each other (H11).

Figure 1 shows the independent, mediating and dependent variables of the research. 


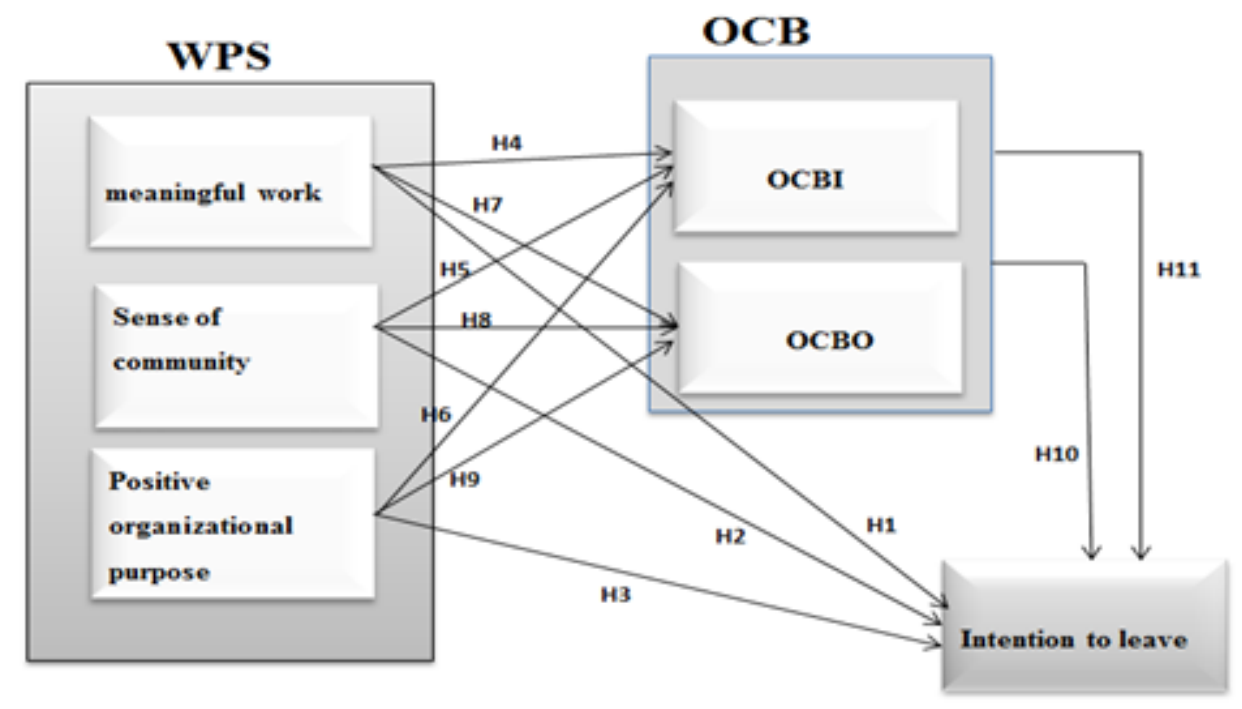

Figure 1. The research theoretical framework

\section{Methods}

\subsection{Study design}

A descriptive correlational survey that utilized quantitative methodology was designed to study the associations between workplace spirituality, intention to leave, and OCB. In addition to these direct associations, the indirect(mediating) effect of OCB towards workplace spirituality and OCB was also tested. Responses from a questionnaire survey were collected as data.

\subsection{Population and sampling}

Approximately 3300 registered nurses employed by three public hospitals in Joh or Bahru were chosen as the target population. From this number, random sampling was then conducted. With a confidence level of $95 \%$ and margin of error at 5\%, 346 nurses were chosen as the sample size according to the Krejcie and Morgan (1970) sampling table. To buffer the possibility of the loss of participants, the sample size was increased by a further $10 \%$. Stratified sampling was employed to determine the final number of nurses for each hospital. 


\subsection{Data collection}

Are search package consisting of the questionnaires and the letter of instruction were distributed to the targeted respondents. The letter explained the aim soft here search, voluntary nature of respondents' participation and assurance of confidentiality and anonymity of respondents' information and data. A total of 371 questionnaires were distributed to nurses in July 2014, of which 228 were returned completed and statistically evaluated. It garnered a high response rate of $66.8 \%$. Because this survey was conducted in Malaysia and nurses normally used the Malay language for everyday patient care, it was inappropriate to conduct this survey in English, even though many nurses have sufficient proficiency in English to understand an English questionnaire. Hence, the English-language version of the questionnaire was translated into the Malay language in order to improve the nurses' reading and understanding of the questions.

\subsection{Measurements}

To measure workplace spirituality, a17 -item three- dimensional scale was adapted from the work of Duchon and Plowman (2005). The reliability of the instrument for each dimension possess a Cronbach's $\alpha$ value ranging from 0.88 to 0.94 , as reported by Milliman et al. (2003). The intention to leave scale consisting of seven items was used in this study to measure intentions of employees to resign from their organizations. This scale was developed by Camman, Fichman, Jenkins \& Klesh (1979). Alpha Cronbach for this dimension was 0.76. OCB was measured using adapted twodimensional scales (OCBO and OCBI). A scale consisting of 16 items in this study was used to measure OCBI and OCBO. This scale was developed by Lee and Allen (2002) and also used by Williams and Anderson (1991). Out of the total 16, half of the items were used to measure OCBO. The other half was used to measure OCBI. The Alpha Cronbach for these dimensions was 0.86 for OCBI and 0.90 for OCBO. For this study, a 5 -point Likert- type scale with responses ranging from 1 (strongly disagree) to 5 (strongly agree) was employed. 


\subsection{Data analysis}

The Structural Equation Modelling (SEM) technique, namely Partial Least Square (PLS), was used to analyse the data. Descriptive statistics were employed to analyse demographic variables. For this study, the research model was assessed using a two-step process:

- the measurement model assessment and

- the structural model assessment.

Overall, model validation was used to conclude whether the measurement and structural models fulfil the criteria for empirical work (Urbach \& Ahlemann, 2010). To test the mediating effects, the Baron and Kenny's (1986) path analysis procedure, which included four steps, was used.

\section{Result}

\subsection{Demographic characteristics}

Among the respondents, $97.8 \%$ were female, 39\% ranged from 25 to 30 years of age, $61.4 \%$ were married, 98.2\% were fulltime nurses, and approximately one third (36\%) possessed nursing experience ranging from 1 to 3 years, whereas approximately $24.6 \%$ of the nurses had 4 to 6 years of experience. The demographics are presented in Table 1. 


\begin{tabular}{|c|c|}
\hline Characteristics of nurses & N (\%) \\
\hline \multicolumn{2}{|l|}{ Gender } \\
\hline Female & $223(97.8)$ \\
\hline Male & $5(2.2)$ \\
\hline \multicolumn{2}{|l|}{ Age } \\
\hline $19-24$ & $52(22.8)$ \\
\hline $25-30$ & $89(39)$ \\
\hline $31-40$ & $47(20.6)$ \\
\hline $41-50$ & $30(13.2)$ \\
\hline Above 51 & $10(4.4)$ \\
\hline \multicolumn{2}{|l|}{ Marital status } \\
\hline Single & $82(36)$ \\
\hline Married & $140(61.4)$ \\
\hline Divorce & $6(2.6)$ \\
\hline \multicolumn{2}{|l|}{ Work status } \\
\hline Temporary & $2(0.9)$ \\
\hline Part time & $2(0.9)$ \\
\hline Full time & $224(98.2)$ \\
\hline \multicolumn{2}{|l|}{ Working experiences } \\
\hline $1-3$ & $82(36)$ \\
\hline $4-6$ & $56(24.6)$ \\
\hline $7-10$ & $35(15.3)$ \\
\hline More than 10 & $55(24.1)$ \\
\hline
\end{tabular}

Table 1. Respondent Demographics $(\mathrm{N}=228)$

\subsection{Measurement model analysis}

\subsubsection{Reliability tests}

The Cronbach's alpha (CA) and composite reliability were used for testing the internal consistency of the items. According to Hair, Hult, Ringle and Sarstedt (2014), composite reliability (CR) and CA values are greater than 0.8 or 0.9 suggesting satisfactory level of construct reliability. Moreover, the indicator reliability shows the variance rate of an indicator that comes from the latent variables. For the elucidation of not less than $50 \%$ of the variance of latent variable by the indicators, each value has to reach 0.708 or higher. The significance of the indicator loadings was tested using the boot strapping method.

According to the results shown in Table 2, all constructs have a satisfactory level of internal consistency. As indicated in Table 2, the indicator loadings for four items are less than 0.4. ITL 2, OCBI 1, OCBI 8 and OCBO 1 need to be removed. Those items with loading between 0.4 and 0.7 were checked to determine whether their removal led to increased CR or AVE. As their CR or AVE were not changed, those items were kept for further analysis. 


\begin{tabular}{|c|c|c|c|c|c|}
\hline Variables & $\begin{array}{c}\text { Cronbach's } \\
\text { Alpha }\end{array}$ & $\begin{array}{l}\text { Composite } \\
\text { Reliability }\end{array}$ & AVE & Items & $\begin{array}{l}\text { Indicator } \\
\text { reliability }\end{array}$ \\
\hline ITL & 0.825 & 0.873 & 0.535 & $\begin{array}{l}\text { ITL1 } \\
\text { ITL2 } \\
\text { ITL3 } \\
\text { ITL4 } \\
\text { ITL5 } \\
\text { ITL6 } \\
\text { ITL7 }\end{array}$ & $\begin{array}{r}0.662 \\
0.299 \\
0.670 \\
0.81 \\
0.802 \\
0.664 \\
0.765\end{array}$ \\
\hline OCBO & 0.89 & 0.915 & 0.661 & $\begin{array}{l}\text { OCBO1 } \\
\text { OCBO2 } \\
\text { OCBO3 } \\
\text { OCBO4 } \\
\text { OCBO5 } \\
\text { OCBO6 } \\
\text { OCBO } 7 \\
\text { OCBO } 8\end{array}$ & $\begin{array}{l}0.277 \\
0.804 \\
0.749 \\
0.839 \\
0.716 \\
0.853 \\
0.865 \\
0.851\end{array}$ \\
\hline OCBI & 0.785 & 0.836 & 0.501 & $\begin{array}{l}\text { OCBI1 } \\
\text { OCBI2 } \\
\text { OCBI3 } \\
\text { OCBI4 } \\
\text { OCBI5 } \\
\text { OCBI6 } \\
\text { OCBI7 } \\
\text { OCBI8 }\end{array}$ & $\begin{array}{r}0.390 \\
0.741 \\
0.580 \\
0.62 \\
0.746 \\
0.693 \\
0.759 \\
0.417\end{array}$ \\
\hline MW & 0.873 & 0.905 & 0.613 & $\begin{array}{l}\text { MW1 } \\
\text { MW2 } \\
\text { MW3 } \\
\text { MW4 } \\
\text { MW5 } \\
\text { MW6 }\end{array}$ & $\begin{array}{l}0.770 \\
0.780 \\
0.840 \\
0.799 \\
0.753 \\
0.752\end{array}$ \\
\hline POP & 0.781 & 0.86 & 0.607 & $\begin{array}{l}\text { POP1 } \\
\text { POP2 } \\
\text { POP3 } \\
\text { POP4 }\end{array}$ & $\begin{array}{l}0.677 \\
0.768 \\
0.854 \\
0.806\end{array}$ \\
\hline SOC & 0.87 & 0.903 & 0.608 & $\begin{array}{l}\text { SOC1 } \\
\text { SOC2 } \\
\text { SOC3 } \\
\text { SOC4 } \\
\text { SOC5 } \\
\text { SOC6 }\end{array}$ & $\begin{array}{l}0.793 \\
0.772 \\
0.659 \\
0.827 \\
0.792 \\
0.824\end{array}$ \\
\hline
\end{tabular}

Note. ITL=intention to leave; $\mathrm{OCBO}=$ organization citizenship behaviors towards the organization; $\mathrm{OCBI}=$ organization citizenship behaviors towards the individuals; $\mathrm{MW}=$ meaningful work; $\mathrm{POP}=$ positive organizational purpose; $\mathrm{SOC}=$ sense of community

Table 2. Results of reliability (Internal Consistency and Indicator Reliability) 


\subsubsection{Validity tests}

In this study, the confirmatory factor analysis (CFA) for assessing the validity of the item's workplace spirituality, OCB and intention to leave indicated a good fit for all the scales. Given that the Confirmatory Factor Analysis (CFA) focuses only on the relationship between factors and their underlying items within the SEM (Byrne, 2010), it is more suitable than other approaches, such as exploratory factor analysis (Moustaki, 2001). Construct validity involves convergent validity and discriminant validity (MacKenzie Podsakoff \& Podsakoff, 2011). In this study, the measurement model's convergent validity was weighed by investigating its average variance extracted (AVE) value. Convergent validity is acceptable if constructs achieve at least 0.5 AVE value. As shown in Table 2, all constructs have AVE ranging from 0.535 to 0.661, which is more than the recommended threshold value of 0.5 . In addition, the measurement model's discriminant validity is assessed using two measures, namely Fornell and Larcker's criterion (1981) and cross loading. A measurement model has discriminant validity when the square root of the AVE exceeds the correlations between the measure and all other measures and the indicators' loadings are higher against their respective construct compared to other constructs. Therefore, based on the results, all square roots of AVE exceeded the off-diagonal elements in their corresponding row and column (see Table 3). The second assessment of discriminant validity is to examine the indicators' loadings with respect to all construct correlations. According to the results, all measurement items loaded higher against their respective intended latent variable compared to other variables. The result is attached in Appendix 1. Overall, the reliability and validity tests conducted on the measurement model are satisfactory.

\begin{tabular}{|l|r|r|r|r|r|r|}
\cline { 2 - 8 } \multicolumn{1}{c|}{} & \multicolumn{1}{c|}{ ITL } & \multicolumn{1}{c|}{ MW } & \multicolumn{1}{c|}{ CBI } & \multicolumn{1}{c|}{ CBO } & \multicolumn{1}{c|}{ POP } & \multicolumn{1}{c|}{ SOC } \\
\hline ITL & 0.731 & & & & & \\
\hline MW & -0.55 & 0.783 & & & & \\
\hline OCBI & -0.394 & 0.571 & 0.708 & & & \\
\hline OCBO & -0.399 & 0.617 & 0.665 & 0.813 & & \\
\hline POP & -0.48 & 0.633 & 0.479 & 0.548 & 0.779 & \\
\hline SOC & -0.49 & 0.729 & 0.528 & 0.636 & 0.671 & 0.78 \\
\hline
\end{tabular}

Table 3. Fornell-Larcker criterion 


\subsection{Structural model analysis}

The structural model is assessed using the coefficient of determination (R2), path coefficients, and Pvalue (Hair et al., 2014). As Figure 2 presents, 34\% percent of the variance in the intention to leave (ITL) has been significantly explained by meaningful work, sense of community and positive organizational purpose, OCBI, OCBO. Moreover, it shows that 36 percent of OCBI and 45 percent of OCBO variance have been significantly explained by meaningful work, sense of community and positive organizational purpose. Therefore, it indicates that the influence of workplace spirituality on the variation of $\mathrm{OCBO}$ is at least twice greater than the respective influence on OCBI. In terms of the path coefficients, it can be said that all hypothesized paths are significant, as shown in Table 4. The detailed information on these results is provided in following section.

\begin{tabular}{|l|r|r|r|r|c|c|}
\cline { 2 - 7 } \multicolumn{1}{c|}{} & \multicolumn{1}{c|}{$\begin{array}{c}\text { Path } \\
\text { coefficient }\end{array}$} & St. Error & t-value & P-value & $\begin{array}{c}\text { Significance } \\
\text { Level }\end{array}$ & Result \\
\hline MW -> ITL & -0.278 & 0.091 & 3.055 & 0.003 & $* *$ & Supported \\
\hline MW -> OCBI & 0.345 & 0.081 & 4.25 & 0.000 & $* * *$ & Supported \\
\hline MW -> OCBO & 0.318 & 0.089 & 3.555 & 0.000 & $* * *$ & Supported \\
\hline OCBI -> ITL & -0.205 & 0.079 & 2.317 & 0.021 & $*$ & Supported \\
\hline OCBO -> ITL & -0.193 & 0.077 & 2.012 & 0.045 & $*$ & Supported \\
\hline POP -> ITL & -0.206 & 0.087 & 2.38 & 0.018 & $*$ & Supported \\
\hline POP -> OCBI & 0.263 & 0.086 & 3.605 & 0.000 & $* * *$ & Supported \\
\hline POP -> OCBO & 0.207 & 0.062 & 3.321 & 0.001 & $* * *$ & Supported \\
\hline SOC -> ITL & -0.187 & 0.078 & 1.984 & 0.048 & $*$ & Supported \\
\hline SOC -> OCBI & 0.226 & 0.075 & 3.206 & 0.002 & $* *$ & Supported \\
\hline SOC -> OCBO & 0.246 & 0.07 & 3.494 & 0.001 & $* * *$ & Supported \\
\hline
\end{tabular}

Note $2:{ }^{*} \mathrm{p}<0.05 ;{ }^{* *} \mathrm{p}<0.01 ;{ }^{* * *} \mathrm{p}<0.001$

Table 4. Results of the Significance and Relevance of the Structural Model Relationships

\subsubsection{Relationships between dimensions of workplace spirituality and intention to leave}

Structural model analysis showed the significant and negative influence of meaningful work on nurses' intention to leave $(\beta=-0.278, p<0.01)$, significant and negative influence of sense of community on nurses' intention to leave $(\beta=-0.187, p<0.05)$, and significant and negative influence of positive organizational purpose on nurses' intention to leave $(\beta=-0.206, p<0.05)$. This indicates that three dimensions of workplace spirituality independently influence nurses to show lower levels of turnover. To assess the strength of the influence of workplace spirituality's dimensions on intention to leave, Table 4 presents the results in a coefficient table. After analysing the scale of the coefficients, the 
variable with the largest $\beta$ value has the greatest impact on the dependent variable (Sekaran, 2005). These path coefficient results proved that meaningful work has the greatest influence among nurses to show lower levels of turnover. This means that when the worker feels highly invigorated through work that grants personal purpose and meaning, this will guide workers towards strong intention to continue to work instead of intention to leave. Furthermore, the lowest level of nurses' intention to leave occurred when nurses who had communications between colleagues in their workplace showed lower levels of turnover in the hospitals. Their positive organizational purpose was not significant because it possesses a very low $\beta$ value, indicating no positive organizational purpose as well as having no meaningful work and sense of community to show the low level of intention to leave. This result reflects a significant negative relationship between workplace spirituality's dimensions and intention to leave.

\subsubsection{Relationships between dimension of workplace spirituality and OCBI and OCBO}

Structural model analysis (Table 4) indicated the significant and positive influence of meaningful work $(\beta=0.345, p<0.001)$, sense of community $(\beta=0.226, p<0.01)$, and positive organizational purpose $(\beta=0.263, p<0.001)$ on the nurses' OCBI. Referring to Table 4 , meaningful work achieved the highest $\beta$ value. This explains why professional nurses who are highly connected with their jobs and feel greater purpose and meaning in the course of their experienced is play supportive behaviours and also demonstrate other OCBI acts. Positive organizational purpose has the second highest $\beta$ value and was more significant than the sense of community. This finding indicates that nurses are more engaged in showing the OCBI acts when they experience a solid connection with their organization's values. In addition, structural model analysis (Table 4) indicated the significant and positive influence of meaning fulwork $(\beta=0.318, p<0.001)$, sense of community $(\beta=0.246, p<0.001)$, and positive organizational purpose $(\beta=0.207, p<0.001)$ on the nurses' OCBO. These path coefficient results showed that meaningful work is the factor with greatest influence on nurses to show positive behaviour and attitude to their organization. Sense of community is the second most influential factor and was more significant than positive organizational purpose. This result shows a significant positive relationship between workplace spirituality's dimensions and OCBI and OCBO. 


\subsubsection{Relationships between dimensions of OCB and intention to leave}

Structural model analysis (Table 4) shows the significant and negative influence of OCBI on nurses' intention to leave $(\beta=-0.205, p<0.05)$ and significant and negative influence of OCBO on nurses' intention to leave $(\beta=-0.193, p<0.05)$. These path coefficient results showed that OCBO was considerably more significant than OCBI. This suggests that when the nurses demonstrate behaviours such as conforming to informal regulations and volunteering themselves for teams or committees, they exhibit a reduced intention to leave.

\subsection{Mediation effect}

To test whether a nurse's organizational citizenship behaviour mediates the relationship between workplace spirituality and intention to leave, we used the Sobel test (Sobel, 1982) and Baron and Kenny's (1986) steps, which is the most common method. According to Baron and Kenny (1986), the Sobel test represents a rigorous, conservative, and confirmatory method to test mediation. The coefficient value of the direct path between meaningful work and intention to leave was $\beta=-0.278$ before the OCBI was introduced as a mediator. When OCBI was introduced as mediator, the amount of the coefficient value reduced from -0.278 to -0.297 . The significance of the mediation effect was assessed using the Sobel test. The z-value of OCBI was $-2.206, p<0.05$.

The coefficient value of the second analysis between sense of community and intention to leave was $\beta=-0.187$ when the link was direct. When OCBI was included as a mediator, the amount of the coefficient value reduced from -0.187 to -0.201 . The $z$-value of OCBI was $-1.965, p<0.05$. The coefficient value of the third analysis between positive organizational purpose and intention to leave was $\beta=-0.206$. When OCBI was introduced as mediator, the amount of the coefficient value reduced from -0.206 to -0.223 . The $z$-value of OCBI was $-1.97, p<0.05$.

Next, our results show the mediating analysis conducted to examine the mediating effect of OCBO on intention to leave. The coefficient value of the analysis between meaningful work and intention to leave was $\beta=-0.278$ when the link was direct. When OCBO was included as a mediator, the amount of the coefficient value reduced from -0.278 to -0.290 . The $z$-value of OCBO provided by the Sobel test was $-2.038, p<0.05$. The coefficient value of second direct path between sense of community and intention to leave was $\beta=-0.187$ before the OCBI was introduced as a mediator. When OCBO was introduced as mediator, the amount of the coefficient value reduced from -0.187 to -0.193 . The $z$-value of OCBO 
provided by the Sobel test was $-2.027, p<0.05$. The coefficient value of the third analysis between positive organizational purpose and intention to leave was $\beta=-0.206$. When OCBO was introduced as mediator, the amount of the coefficient value reduced from -0.206 to -0.219 . The $z$-value of OCBO provided by the Sobel test was $-1.991, p<0.05$. Based on Baron and Kenny's steps, the first three conditions are confirmed in our model (see Table 5). Thus, OCBI and OCBO did partially mediate the relationship between workplace spirituality and intention to leave.

\section{Discussion}

According to previous literature, workplace spirituality is inversely associated with intention to leave (Milliman et al., 2003; Hong, 2012). This hypothesis was supported in this study, and empirical evidence suggests that workplace spirituality reduces the intention to leave among nurses. In addition, if nurses find their duties meaningful, have better relationships with their colleagues, and are in accord with the hospital's values, they will be more emotionally attached to their organization. The results from this study also indicated that with workplace spirituality, nurses have fewer tendencies towards wanting to resign, and by extension it improves their satisfaction and service quality. The findings also provide clear empirical evidence in support of Hong's (2012) and Kinjerski and Skrypnand's (2008) studies, which showed that when nurses derive greater meaning and purpose from their work in hospitals, the occurrence of resignation indicators decreases. The findings also support the notion that with better integrity between nurses' and hospitals' aims, nurses are more likely to align with the hospitals' visions. This situation allows the nurses to have a sense of belonging, and therefore, they will always attempt to show the best side of their hospital. It also reduces the tendencies towards resignation.

In addition, the research findings show that workplace spirituality increases performance of OCB among nurses (Kazemipour et al., 2012; Pawar, 2009; Rego \& Cunha, 2008), which supports the new construct in the model of workplace spirituality influencing OCB among the employees. If nurses find their duties meaningful, have better relationships with their colleagues, and are in agreement with the values of the hospital, they will also exhibit more positive acts that help the organization even in the absence of a reward system. The study results also indicate that OCB (OCBI and OCBO) improves nurse-patient relationships to the benefit of patient care and their hospital, and by extension improves their satisfaction and the quality of services provided to patients. Further more, in comparison to the research conducted by Milliman et al. (2003) and Kazemipour et al.(2012), this research clarifies that meaningful work is the greatest factor informing OCBO and OCBI. Therefore, by putting more focus 
on workplace spirituality, nurses' OCBI and OCBO can be enhanced. Moreover, the link between intention to leave and OCB was elucidated in previous research (Regts \& Molleman, 2013; Tsai \& Wu, 2010). To counter act the national nursing shortage, the most important element is organizational citizenship behaviour in support of the preservation of nursing (Tsai \& Wu, 2010). In addition, our results denote that OCBI has an influence on the balance of social interaction between employees and peers and can decrease the willingness to leave thus, our results explain how OCBO behaviours have an influence on the balance of social interactions between employees and the organization and can decrease the willingness to leave. However, in this research, OCBI denotes the nurses' propensity to provide assistance to other colleagues to resolve their issues related to work, resulting in decreased intention to leave. OCBO denotes the advantageous behaviours such as conforming to the informal regulations and volunteering for teams or committees (for example, providing advance notice of work absences) that are destined to maintain constancy in the firm. Furthermore, the findings of this research note that $\mathrm{OCBO}$ more significantly impacts intention to leave than OCBI. Thus, nurses' intention to leave is influenced by OCBO and OCBI, which will eventually influence the service quality given to patients in hospital. Based on previous studies on this subject, these results prove the concepts of Tsai and Wu (2010) and Kazemipour et al. (2012) that had not been supported in previous studies. Many studies have touched upon the topics of this research, including workplace spirituality, intention to leave, dimensions of meaningful work, sense of community, and positive organizational purpose, and yet, this subject has not been investigated in any prior empirical research. It has been theoretically and conceptually mentioned (Podsakoff et al., 2009; Tsai \& Wu, 2010; Krishnan \& Singh, 2010).

Remarkably, this study has shown that through the influence of OCB as a vital positive employee attitude, workplace spirituality reduces the nurses' intention to leave, directly or indirectly. It was also shown through OCB's effect that nurses who perform more positive and extra role behaviours are less willing to leave the organization. This finding contributes to the knowledge of the impact of workplace spirituality on the intention to leave and the advantages of OCB for hospitals, particularly among nurses. 


\section{Limitations of the study}

Although a significant research design was made, certain limitations must be mentioned. First, a stratified sampling was used from only three public and general hospitals in a single country. Similar studies may differ in other countries. In addition, most of the participants were female nurses. Hence, the results can not be generalized to both the male and female nurses. Moreover, although this study tested the reliability of all of the scales, the OCB, intention to leave and workplace spirituality instruments were evaluated by respondents' self-reported ratings. Thus, the information related to these factors depends entirely upon how accurately respondents answered the questionnaire. Finally, because the study gathered the data on the basis of cross-sectional method, the findings can not conclusively establish causality.

\section{Conclusion and recommendations}

The results in this study support the notion that workplace spirituality helps to curb high turnover rates by reducing the intentions of leaving. This information should be considered by hospital managers as they attempt to improve service within the healthcare system. This would provide a clearer picture on how meaningful nurses feel in performing their duties, how strong the collegial relationships within the hospital are and whether the nurses are in agreement with the values of the hospital. By achieving this, managers can hopefully detect intention to leave and the level of nurses' OCB, and such information from these evaluations could allow earlier action, either by interventions, meetings or workshops, to curb the high rates of resignation. Because addressing the rising turnover rates is crucial, workplace spirituality may be the answer to these problems, thereby making it vital to ensure patient care quality.

Low citizenship behaviours have serious implications. They hinder good performance and impact the organization's image. In addition, such behaviours also lead to low morale among nurses and a damaging work culture in hospitals. For these reasons, administrators should focus on providing the best conditions to support workplace spirituality and to enhance nurses' OCB. However, further studies could be conducted at different types of businesses and jobs, with data from both males and females. In addition, further studies could be conducted to determine the degree of OCB both before and after the implementation of workplace spirituality. Finally, by relating the study to $O C B$, the scope was minimized, and further research could be conducted to examine the influence of workplace spirituality on different attitudinal outcomes, such as job involvement and job satisfaction. 


\section{Implications for nursing management}

The purpose of this study is to explain the potential advantages that the three dimensions of workplace spirituality have on intention to leave and OCB among nurses. Hospital management should take workplace spirituality into account due to its positive impact on nurses' performance, and by extension, the entire healthcare system. Findings from this study would allow managers to recognize the levels of meaningful work, sense of community and positive organizational purpose existing among their nurses. Moreover, this study also illustrates the magnitude of these factors' impact on OCB and intention to leave. To improve these levels, interventions such as meetings and workshops should be conducted. Such activities foster stronger bonding between the managers and nurses whereby the latter could provide feedback from their perspectives on how to improve their perceptions of meaningful work, sense of community and positive organizational purpose with regards to nursing management. Healthcare service quality improves if the working environment encourages the involvement of spirituality. Therefore, meaningful work, sense of community and alignment with hospital values amongst nurses are important factors and should be taken into account by managers in their efforts to improve the bond between the nurses, their jobs, their colleagues and the respective health organizations.

\section{References}

Altuntas, S., \& Baykal, U. (2010). Relationship between nurses' organizational trust levels and their organizational citizenship behaviors. Journal of Nursing Scholarship, 42(2), 186-194. https://doi.org/10.1111/j.1547-5069.2010.01347.x

Ashmos, D.P., \& Duchon, D. (2000). Spirituality at work: a conceptualization and measure. Journal of Management Inquiry, 9(2), 134-145. https://doi.org/10.1177/105649260092008

Avey, J.B., Wernsing, T.S., \& Luthans, F. (2008). Can positive employees help positive organizational change? Impact of psychological capital and emotions on relevant attitudes and behaviors. The Journal of Applied Behavioral Science, 44(1), 48-70. https://doi.org/10.1177/0021886307311470

Baron, R.M., \& Kenny, D.A. (1986). The moderator-mediator variable distinction in social psychological research: Conceptual, strategic, and statistical considerations. Journal of personality and social psychology, 51(6), 1173. https://doi.org/10.1037/0022-3514.51.6.1173 
Byrne, B.M. (2010). Structural equation modeling with EQS: Basic concepts, applications, and programming (2nd ed.). Mahwah, NJ: Erlbaum.

Camman, C., Fichman, M., Jenkins, D., \& Klesh, J. (1979). The Michigan organizational assessment questionnaire. Unpublished Manuscript, Universty of Michigan, Ann Arbor, MI.

Carroll, B. (2001). A phenomenological exploration of the nature of spirituality and spiritual care. Mortality, 6(1), 81-98. https://doi.org/10.1080/13576270020028656

Chalofsky, N., \& Krishna, V. (2009). Meaningfulness, commitment, and engagement:the intersection of a deeper level of intrinsic motivation. Advances in Developing Human Resources, 11(2), 189-203. https://doi.org/10.1177/1523422309333147

Cohen, A., \& Golan, R. (2007). Predicting absenteeism and turnover intentions by past absenteeism and work attitudes: An empirical examination of female employees in long term nursing care facilities. Career Development International, 12(5), 416-432. https://doi.org/10.1108/13620430710773745

Duchon, D., \& Plowman, D.A. (2005). Nurturing the spirit at work: Impact on work unit performance. The Leadership Quarterly, 16(5), 807-833. doi: http://dx.doi.org/10.1016/j. leaqua.2005.07.008.

Fornell, C., \& Larcker, D.F. (1981). Evaluating structural equation models with unobservable variables and measurement error. Journal of Marketing Research, 18(1), 39-50. https://doi.org/10.2307/3151312

Hair, J.F., Hult, G.T., Ringle, C.M., \& Sarstedt, M. (2014). A primer on partial least squares structural equation modeling (PLS-SEM). United Kingdom: Sage

Harrington, W.J., Preziosi, R.C., \& Gooden, D.J. (2004). Worldview resiliency of business degree graduate students-An examination of spiritual experiences and psychological attitudes. Association on Employment Practices and Principles, 119.

Hayes, L.J., O’Brien-Pallas, L., Duffield, C., Shamian, J., Buchan, J., Hughes, F. et al. (2006). Nurse turnover: A literature review. International Journal of Nursing Studies, 43(2), 237-263.

https://doi.org/10.1016/j.ijnurstu.2005.02.007

Heinen, M.M., van Achterberg, T., Schwendimann, R., Zander, B., Matthews, A., Kózka, M. et al. (2013). Nurses' intention to leave their profession: a cross sectional observational study in 10 European countries. International Journal of Nursing Studies, 50(2), 174-184.

https://doi.org/10.1016/j.ijnurstu.2012.09.019

Hicks, D.A. (2003). Religion and the workplace: Pluralism, spirituality, leadership. Cambridge University Press. https://doi.org/10.1017/cbo9780511615474 
Hong, Y.J. (2012). Identifying Spirituality in Workers: A Strategy for Retention of Community Mental Health Professionals. Journal of Social Service Research, 38(2), 175-186. https://doi.org/10.1080/01488376.2011.615275

Kazemipour, F., Mohamad Amin, S., \& Pourseidi, B. (2012). Relationship between workplace spirituality and organizational citizenship behavior among nurses through mediation of affective organizational commitment. Journal of Nursing Scholarship, 44(3), 302-310. https://doi.org/10.1111/j.15475069.2012.01456.x

Kinjerski, V., \& Skrypnek, B.J. (2008). The promise of spirit at work: increasing job satisfaction and organizational commitment and reducing turnover and absenteeism in long-term care. Journal of Gerontological Nursing, 34(10), 17-25; quiz 26-17. https://doi.org/10.3928/00989134-20081001-03

Komala, K., \& Ganesh, L. (2007). Individual spirituality at work and its relationship with job satisfaction and burnout: An exploratory study among health care professionals. The Business Review, Cambridge, 7(1), 124-129.

Krejcie, R.V., \& Morgan, D.W. (1970). Determining sample size for research activities. Educational and Psychological Measurement, 30(3), 607-610. https://doi.org/10.1177/001316447003000308

Krishnakumar, S., \& Neck, C.P. (2002). The "what", "why" and "how" of spirituality in the workplace. Journal of Managerial Psychology, 17(3), 153-164. https://doi.org/10.1108/02683940210423060

Krishnan, S.K., \& Singh, M. (2010). Outcomes of intention to quit of Indian IT professionals. Human Resource Management, 49(3), 421-437. https://doi.org/10.1002/hrm.20357

Laschinger, H.K.S., Finegan, J., \& Shamian, J. (2001). The impact of workplace empowerment, organizational trust on staff nurses' work satisfaction and organizational commitment. Health Care Management Review, 26(3), 7-23. https://doi.org/10.1097/00004010-200107000-00002

Lazar, A. (2010). Spirituality and job satisfaction among female Jewish Israeli hospital nurses. Journal of Advanced Nursing, 66(2), 334-344. https://doi.org/10.1111/j.1365-2648.2009.05172.x

Lee, K., \& Allen, N.J. (2002). Organizational citizenship behavior and workplace deviance: The role of affect and cognitions. Journal of Applied Psychology, 87(1), 131. https://doi.org/10.1037/0021-9010.87.1.131

MacKenzie, S.B., Podsakoff, P.M., \& Podsakoff, N.P. (2011). Construct measurement and validation procedures in MIS and behavioral research: Integrating new and existing techniques. MIS Quarterly, 35(2), 293-334. 
Milliman, J., Czaplewski, A.J., \& Ferguson, J. (2003). Workplace spirituality and employee work attitudes: An exploratory empirical assessment. Journal of Organizational Change Management, 16(4), 426-447. https://doi.org/10.1108/09534810310484172

Moustaki, I. (2001). A review of exploratory factor analysis for ordinal categorical data. In R. Cudeck, S. du Toit, \& D. Sorbom (Eds.), Structural equation modeling: Present and future (pp. 461-480). Lincolnwood, IL: Scientific Software.

Organ, D.W. (1988). Organizational citizenship behavior: The good soldier syndrome. Lexington, Massachusetts/Toronto: Books/DC Heath and Com.

Organ, D.W., Podsakoff, P.M., \& MacKenzie, S.B. (2006). Organizational citizenship behavior: Its nature, antecedents, and consequences. Thousand Oaks, CA: Sage Publications.

Pawar, B. (2009). Workplace Spirituality Facilitation: A Comprehensive Model. Journal of Business Ethics, 90(3), 375-386. https://doi.org/10.1007/s10551-009-0047-7

Pesut, B. (2013). Nursings' need for the idea of spirituality. Nursing inquiry, 20(1), 5-10. https://doi.org/10.1111/j.1440-1800.2012.00608.x

Podsakoff, N.P., Whiting, S.W., Podsakoff, P.M., \& Blume, B.D. (2009). Individual-and organizationallevel consequences of organizational citizenship behaviors: A meta-analysis. Journal of Applied Psychology, 94(1), 122. https://doi.org/10.1037/a0013079

Podsakoff, P.M., MacKenzie, S.B., Paine, J.B., \& Bachrach, D.G. (2000). Organizational citizenship behaviors: A critical review of the theoretical and empirical literature and suggestions for future research. Journal of management, 26(3), 513-563. https://doi.org/10.1177/014920630002600307

Rego, A., \& Cunha, M.P. (2008). Workplace spirituality and organizational commitment: An empirical study. Journal of Organizational Change Management, 21(1), 53-75. https://doi.org/10.1108/09534810810847039

Regts, G., \& Molleman, E. (2013). To leave or not to leave: When receiving interpersonal citizenship behavior influences an employee's turnover intention. Human Relations, 66(2), 193-218. https://doi.org/10.1177/0018726712454311

Sekaran, U. (2005). Research methods for business: A skill building approach (4th ed.). United States of America: Wiley, Islamabad.

Sobel, M.E. (1982). Asymptotic Confidence Intervals for Indirect Effects in Structural Equation Models. Sociological Methodology, 13, 290-312. https://doi.org/10.2307/270723 
Tsai, Y., \& Wu, S.W. (2010). The relationships between organisational citizenship behaviour, job satisfaction and turnover intention. Journal of clinical nursing, 19(23-24), 3564-3574. https://doi.org/10.1111/j.1365-2702.2010.03375.x

Urbach, N., \& Ahlemann, F. (2010). Structural equation modeling in information systems research using partial least squares. Journal of Information Technology Theory and Application, 11(2), 5-40.

Whitman, D.S., Van Rooy, D.L., \& Viswesvaran, C. (2010). Satisfaction, citizenship behaviors, and performance in work units: A meta-analysis of collective construct relations. Personnel Psychology, 63(1), 41-81. https://doi.org/10.1111/j.1744-6570.2009.01162.x

Williams, L.J., \& Anderson, S.E. (1991). Job satisfaction and organizational commitment as predictors of organizational citizenship and in-role behaviors. Journal of management, 17(3), 601-617. https://doi.org/10.1177/014920639101700305

\section{Appendices}

\section{Part 1: Demographic Data}

\section{Bahagian 1: Maklumat diri}

Please complete the following demographic information.

1-What is your sex? Apakah jantina anda?
a. Female/Perempuan
b. Male/Lelaki

2- What is your age? Berapakah umur anda?
a. 19 to 24 years / 19-24 tahun
b. 25 to 30 years / 25-30 tahun
c. 31 to 40 years / 31-40 tahun
d. 41 to 50 years / 41-50 tahun
e. 51 and above / 51 dan ke atas 
3- What is your current material statues? Apakah status perkahwinan anda?
a. Single / Bujang
b. Married / Berkhawin
c. Divorced / Bercerai

4- What type is your job? Jenis pekerjaan
a. Temporary work / kerja sementara
b. Part-time / separuh masa
c. Full-time / sepenuh masa

5- How long is your do you have experience in nursing job? Berapakah tempoh pengalaman bekerja anda sebagai jururawat?
a. 1-3 years / 1-3 tahun
b. 4-6 years / 4-6 tahun
c. 7-10 years / 7-10 tahun
d. More than 10 years / lebih daripada 10 tahun

\begin{tabular}{|c|c|c|c|c|c|c|c|c|}
\hline Strongly Disagree & Disagree & $\begin{array}{l}\text { Neither Agree } \\
\text { Nor } \\
\text { Disagree }\end{array}$ & \multicolumn{2}{|l|}{ Agree } & \multicolumn{4}{|c|}{ Strongly Agree } \\
\hline $\begin{array}{l}\text { Sangat tidak } \\
\text { setuju }\end{array}$ & Tidaksetuju & $\begin{array}{l}\text { Neutral/Tidak } \\
\text { pasti }\end{array}$ & \multicolumn{2}{|l|}{ Setuju } & \multicolumn{4}{|c|}{ Sangat setuju } \\
\hline \multicolumn{4}{|c|}{ 6-I enjoy my work. / Saya suka kerja saya } & 1 & 2 & 3 & 4 & 5 \\
\hline \multicolumn{4}{|c|}{$\begin{array}{l}\text { 7-My Spirit is energized by my work. / Kerja saya meningkatkan kerohanian } \\
\text { saya }\end{array}$} & 1 & 2 & 3 & 4 & 5 \\
\hline \multicolumn{4}{|c|}{$\begin{array}{l}\text { 8-My work is connected to what I think is important in my life. / Kerja saya } \\
\text { berkaitan dengan apa yang saya rasa penting dalamkehidupan saya }\end{array}$} & 1 & 2 & 3 & 4 & 5 \\
\hline \multicolumn{4}{|c|}{$\begin{array}{l}\text { 9-I look forward to coming to work. / Saya menanti dengan minat untuk pergi } \\
\text { bekerja }\end{array}$} & 1 & 2 & 3 & 4 & 5 \\
\hline \multicolumn{4}{|c|}{$\begin{array}{l}\text { 10-I see a connection between my work and social good. / saya nampak } \\
\text { hubungan di antara kerja saya dengan.......? }\end{array}$} & 1 & 2 & 3 & 4 & 5 \\
\hline \multicolumn{4}{|c|}{$\begin{array}{l}\text { 11-I understand what give to my work personal meaning./ saya faham apa } \\
\text { yang memberikan kerja saya maknaindividu }\end{array}$} & 1 & 2 & 3 & 4 & 5 \\
\hline \multicolumn{4}{|c|}{$\begin{array}{l}\text { 12-My working cooperatively with others is valued./ Kerja secara bersama } \\
\text { dengan orang lain dihargai }\end{array}$} & 1 & 2 & 3 & 4 & 5 \\
\hline \multicolumn{4}{|c|}{ 13-I am a part of my hospital. / saya sebahagian daripadahospital saya } & 1 & 2 & 3 & 4 & 5 \\
\hline \multicolumn{4}{|c|}{$\begin{array}{l}\text { 14-I feel free to express opinions. / Saya bebas untuk memberikan pendapat } \\
\text { saya }\end{array}$} & 1 & 2 & 3 & 4 & 5 \\
\hline \multicolumn{4}{|c|}{$\begin{array}{l}\text { 15-I think nurses are linked with a common purpose. / Saya berpendapat para } \\
\text { jururawat disatukan dengan satu tujuan bersama }\end{array}$} & 1 & 2 & 3 & 4 & 5 \\
\hline \multicolumn{4}{|c|}{$\begin{array}{l}\text { 16-I believe nurses are genuinely care about each other./ Saya percaya para } \\
\text { jururawat sememangnya menjaga satu sama lain }\end{array}$} & 1 & 2 & 3 & 4 & 5 \\
\hline
\end{tabular}


17-I feel there is sense of being as a part of family / Saya berasa ada perasaan semangat sekeluarga di sini

18-My hospital feels concerned for all employees / saya Hospital berasa prihatin terhadap semua pekerjza

19-My hospital worries about the society / hospital saya risau mengenai masyarakat setempat

20-My hospital has a decent and honorable aim/ hospital saya ada satu tujuan yang baik dan dihormati

21-My hospital provides important services to the public at large. / Hospital saya memberikan perkhidmatan yang penting kepada masyarakat secara amnya 22-Since my commencement of employment I have thought occasionally about finding other work. / sejak memulakan pekerjaan ini saya pernah memikirkan tentang mencari pekerjaan lain

23-If it is up to me, I will still work at hospital in two years. / sekiranya terpulang kepada saya, saya akan tetap bekerja di hospital selama dua tahun.

24-As soon as I get the opportunity to work for another hospital, I will take the chance. / sebaik sahaja saya mendapat peluang untuk bekerja di hospital lain, saya akan mengambil peluang tersebut.

25-Within a short period of time I will search actively for a job at another hospital. / dalamjangka masa yang pendek saya akan mencari kerja di hospital lain.

26-I will probably look fora new job in the next year. / saya mungkin akan mencari kerja baru pada tahun hadapan.

27-If I may choose again, I will choose to work for the currenthospital. / sekiranya saya berhak memilih sekali lagi, saya akan memilih untuk kerja di hospital yang sedang saya bekerja.

28-I often think about quitting. / saya sering berfikir untuk berhenti kerja. 29-I help others who have been absent. / saya sering membantu sesiapa yang tidak dapat hadir kerja.

30-I willingly give my time to help others who have work-related problems. / saya sanggup memberi masa saya untuk membantu sesiapa yang mempunyai masalah berkaitan kerja mereka.

31-I adjust my work schedule to accommodate other employees' requests for time off. / saya mengubah jadual kerja saya untuk memenuhi permintaan pekerja lain yang ingin berehat.

32-I go out of the way to make newer employees feel welcome in the work group. / saya mengubah gaya saya bagi membantu pekerja baru supaya merasai bahawa kehadiran mereka disambut baik.

33-I show genuine concern and courtesy toward coworkers, even under the most trying business or personal situations. Saya menunjukkan sikap ambil berat dan berbudi bahasa terhadap rakan sekerja, meskipun di dalamsituasi berkaitan kerja atau peribadi.

34-I give up time to help others who have work or non - work problems. / saya memperuntukkan masa untuk membantu sesiapa yang mempunyai masalah berkaitan kerja atau bukan kerja.

35-I assist others with their duties./saya membantu pekerja lain berkenaan tugas mereka.

36-I share personal properties with other to help their work. / saya berkongsi barang peribadi dengan orang lain untuk membantu kerja mereka.

37-I attend functions that are not required but that help the organizational image. / saya menghadiri majlis yang tidak diperlukan tetapi mampu membantu imej organisasi.

38-I keep up with developments in the organization. / saya sentiasa mengikuti 1 perkembangan di dalam organisasi.

39-I defend the organization when other employees criticize it. / saya mempertahankan organisasi ketika orang lain mengkritik.

40-I show pride when representing the organization in public. / saya mempamerkan organisasi dengan rasa hormat kepada umum.

\begin{tabular}{|c|c|c|c|c|}
\hline 1 & 2 & 3 & 4 & 5 \\
\hline 1 & 2 & 3 & 4 & 5 \\
\hline 1 & 2 & 3 & 4 & 5 \\
\hline 1 & 2 & 3 & 4 & 5 \\
\hline 1 & 2 & 3 & 4 & 5 \\
\hline 1 & 2 & 3 & 4 & 5 \\
\hline 1 & 2 & 3 & 4 & 5 \\
\hline 1 & 2 & 3 & 4 & 5 \\
\hline 1 & 2 & 3 & 4 & 5 \\
\hline 1 & 2 & 3 & 4 & 5 \\
\hline 1 & 2 & 3 & 4 & 5 \\
\hline 1 & 2 & 3 & 4 & 5 \\
\hline 1 & 2 & 3 & 4 & 5 \\
\hline 1 & 2 & 3 & 4 & 5 \\
\hline 1 & 2 & 3 & 4 & 5 \\
\hline 1 & 2 & 3 & 4 & 5 \\
\hline 1 & 2 & 3 & 4 & 5 \\
\hline 1 & 2 & 3 & 4 & 5 \\
\hline 1 & 2 & 3 & 4 & 5 \\
\hline 1 & 2 & 3 & 4 & 5 \\
\hline 1 & 2 & 3 & 4 & 5 \\
\hline 1 & 2 & 3 & 4 & 5 \\
\hline 1 & 2 & 3 & 4 & 5 \\
\hline 1 & 2 & 3 & 4 & 5 \\
\hline
\end{tabular}


41-I offer ideas to improve the functioning of the organization. / saya menawarkan idea untuk memperbaiki fungsi organisasi.

42-I express loyalty toward the organization./ saya menunjukkan kesetiaan kepada organisasi.

43-I take action to protect the organization from potential problems. / saya akan mengambil langkah berjaga-jaga untuk melindungi organisasi daripada masalah yang mendatang.

44-I demonstrate concern about the image of the organization. /saya menunjukkan sikap ambil berat akanimej organisasi.

Intangible Capital, 2017 (www.intangiblecapital.org)

Article's contents are provided on an Attribution-Non Commercial 3.0 Creative commons license. Readers are allowed to copy, distribute and communicate article's contents, provided the author's and Intangible Capital's names are included. It must not be used for commercial purposes. To see the complete license contents, please visit http://creativecommons.org/licenses/by-nc/3.0/. 